\title{
Pengembangan Sarana dan Prasarana untuk Mendukung Pariwisata Pantai yang Berkelanjutan (Studi Kasus: Kawasan Pesisir Pantai Wonokerto Kabupaten Pekalongan)
}

\author{
Syarifah Dina Fajriah', Mussadun ${ }^{2}$
}

Diterima : 2 April 2014

Disetujui : 16 April 2014

\begin{abstract}
Tourism development is development that create added value in all aspects of tourism, ranging from infrastructure, attraction of Tourism, and other aspects. One of the tourism development, among others, the development of coastal tourism. The development must be carried sustainable coastal tourism development. Issues contained in the Wonokerto Coastal Area Tourism is not accommodated well as the existence of its good infrastructure and the absence of supporting public facilities that can support the activities of visitors and tourism are less well-organized system of coastal tourism management by government Pekalongan regency. Based on this, the need for sustainable development of coastal areas. To support this requires facilities that support to achieve all the requirements in order to optimize the area of tourism.
\end{abstract}

Keywords: facility and infrastructure, coastal tourism, sustainable

\section{ABSTRAK}

Pengembangan pariwisata merupakan pembangunan yang menciptakan nilai tambah dalam segala aspek bidang pariwisata, mulai dari sarana dan prasarana, Objek Daya Tarik Wisata (ODTW), dan aspek-aspek lainnya. Salah satu pengembangan pariwisata antara lain yaitu pengembangan pariwisata pesisir. Pengembangan yang dilakukan harus pengembangan pariwisata pesisir yang berkelanjutan. Permasalahan yang terdapat di Kawasan Wisata Pesisir Pantai Wonokerto adalah belum terakodomasi dengan baik kebutuhan pengunjung seperti keberadaan sarana prasarana yang baik dan tidak adanya fasilitas umum pendukung yang dapat menunjang aktivitas pariwisata pengunjung dan kurang tertatanya sistem pengelolaan wisata pesisir oleh pemerintah Kabupaten Pekalongan. Berdasarkan hal tersebut, maka perlu adanya pengembangan wilayah pesisir yang berkelanjutan. Untuk menunjang hal tersebut dibutuhkan sarana dan prasarana yang mendukung guna mencapai semua kebutuhan dalam mengoptimalkan kawasan pariwisata.

Kata kunci: sarana dan prasarana, pariwisata pesisir, berkelanjutan

\footnotetext{
${ }^{1}$ Mahasiswa Magister Pembangunan Wilayah dan Kota, Undip, Semarang, Jawa Tengah

${ }^{2}$ Dosen Jurusan Perencanaan Wilayah dan Kota, Undip, Semarang, Jawa Tengah

Kontak Penulis : dinafajriah43@gmail.com
} 


\section{PENDAHULUAN}

Pembangunan Pariwisata merupakan suatu proses perubahan untuk menciptakan nilai tambah dalam segala aspek bidang pariwisata, mulai dari sarana dan prasarana, Objek Daya Tarik Wisata (ODTW), dan aspek-aspek lainnya. Salah satu bentuk pariwisata yang ada antara lain pariwisata pesisir. Pengembangan pariwisata pesisir sendiri pada dasarnya difokuskan pada pemandangan, karakteristik ekosistem, kekhasan seni budaya dan karakteristik masyarakat sebagai kekuatan dasar yang dimiliki oleh masing-masing daerah. Reaksi atas pengembangan pariwisata ini dapat berupa implikasi negatif berupa terdegradasinya lingkungan akibat eksploitasi sumber daya untuk aktivitas pariwisata, sehingga diperlukan pengelolaan dan pengembangan pariwisata bahari yang berkelanjutan yang memperhatikan kebutuhan generasi saat ini dengan tetap mempertimbangkan kebutuhan (hidup) generasi penerus di waktu yang akan datang. Konsep pariwisata pesisir berkelanjutan (sustainable coastal tourism) adalah pariwisata yang dapat memenuhi kebutuhan wisatawan maupun daerah tujuan wisata pada masa kini, sekaligus melindungi dan mendorong kesempatan serupa dimasa yang akan datang. Pariwisata berkelanjutan mengarah pada pengelolaan seluruh sumberdaya sedemikian rupa sehingga kebutuhan ekonomi, sosial, estetika dapat terpenuhi sekaligus memelihara integritas kultural, proses ekologi essensial keanekaragaman hayati dan sistem pendukung kehidupan (WTO, 1980).

Pengertian tersebut secara implisit menjelaskan bahwa dalam pendekatan pariwisata berkelanjutan bukan berarti hanya sektor pariwisata saja yang berkelanjutan tetapi berbagai aspek kehidupan dan sektor sosial ekonomi lainnya yang ada di suatu daerah (Butler, 1980). Pengembangan wisata pesisir yang berkelanjutan juga dapat memberikan implikasi positif bagi kelestarian lingkungan pesisir. Dalam pengembangnya sarana dan prasarana sangatlah penting dalam menunjang kegiatan pariwisata. Salah satu bentuk pendekatan dalam pengembangan pariwisata adalah pendekatan pengembangan sarana dan prasarana pariwisata, sehingga upaya pemenfaatan dapat dilakukan secara optimal. Dimana aspek sarana dan prasarana memiliki dua sisi kepentingan yaitu sebagai alat memenuhi kebutuhan wisata dan sebagai pengendali dalam rangka memelihara keseimbangan lingkungan. Pada kenyataannya pengembangan pariwisata pesisir masih banyak yang jauh dari konsep pengembangan pariwisata pesisir yang berkelanjutan yang berakibat tidak hanya rusaknya lingkungan juga semakin berkurangnya wisatawan yang datang.

Kawasan wisata pesisir Pantai Wonokerto Kabupaten Pekalongan adalah salah satu kawasan pesisir yang memiliki luas $\pm 71 \mathrm{Ha}$. Memiliki potensi secara fisik berupa adanya kampung nelayan dan TPI yang dapat menjadi pusat aktivitas perekonomian masyarakat serta kondisi pantainya yang landai sehingga dapat mendukung pengembangan aktivitas tersebut. Keberadaan areal pertambakan dan dermaga kapal juga dapat ikut mendukung pengembangan aktivitas pariwisata di Kawasan Pantai Wonokerto sehingga dapat tercipta sebuah kawasan wisata yang memiliki atraksi yang beragam. Permasalahan yang terdapat di Kawasan Wisata Pesisir Pantai Wonokerto adalah belum terakodomasi dengan baik kebutuhan pengunjung seperti keberadaan sarana prasarana yang baik dan tidak adanya fasilitas umum pendukung yang dapat menunjang aktivitas pariwisata pengunjung dan kurang tertatanya sistem pengelolaan wisata pesisir oleh pemerintah Kabupaten Pekalongan. Berdasarkan hal tersebut, maka perlu adanya pengembangan wilayah pesisir yang berkelanjutan. Untuk menunjang hal tersebut dibutuhkan sarana dan prasarana yang mendukung guna mencapai semua kebutuhan dalam mengoptimalkan kawasan pariwisata.

Tujuan dari penelitian ini adalah mengkaji pengembangan sarana dan prasarana untuk 
mendukung pariwisata pantai yang berkelanjutan di Kawasan Pesisir Wonokerto Kabupaten Pekalongan. Sedangkan sasaran yang ingin dicapai antara lain:

1. Mengidentifikasi Kondisi eksisting lokasi studi dalam hal ini adalah kawasan pesisir Pantai Wonokerto.

2. Mengidentifikasi potensi dan permasalahan yang ada pada kawasan studi.

3. Mengidentifikasi jumlah sebaran dan kondisi sarana dan prasarana pesisir dalam pengembangan pariwisata pantai yang berkelanjutan di Kawasan Pesisir Wonokerto Kabupaten Pekalongan.

4. Mengidentifikasi pengguna sarana dan prasarana pesisir dalam pengembangan pariwisata pantai yang berkelanjutan di Kawasan Pesisir Wonokerto Kabupaten Pekalongan.

5. Menganalisis potensi dan permasalahan sarana dan prasarana pesisir dalam pengembangan pariwisata pantai yang berkelanjutan di Kawasan Pesisir Wonokerto Kabupaten Pekalongan.

6. Menganalisis kualitas dan kuantitas sarana dan prasarana pesisir dalam pengembangan pariwisata pantai yang berkelanjutan di Kawasan Pesisir Wonokerto Kabupaten Pekalongan.

7. Menganalisis pengembangan sarana dan prasarana pesisir dalam pengembangan pariwisata pantai yang berkelanjutan di Kawasan Pesisir Wonokerto Kabupaten Pekalongan

\section{METODE PENELITIAN}

Menurut Nazir (2003), metode penelitian merupakan suatu kesatuan sistem dalam penelitian yang terdiri dari prosedur dan teknik yang perlu dilaksanakan dalam suatu penelitian. Penelitian ini menggunakan pendekatan penelitian kualitatif. Peneliti menganalisis keadaan obyek penelitian melalui uraian, pengertian ataupun penjelasan-penjelasan baik terhadap analisis yang bersifat terukur maupun tidak terukur.

Dalam penelitian ini, metode komparatif digunakan dalam analisis jumlah sarana dan prasarana pariwisata pesisir yang ada di Pantai Wonokerto Kabupaten Pekalongan, metode analisis deskriptif kualitatif digunakan untuk mendeskripsikan kondisi eksisting sarana dan prasarana yang akan dianalisis yang meliputi daya tarik/atraksi, aksesibilitas, transportasi, pelayanan, informasi, kenyamanan dan keamanan. Dalam analisis ini juga disertakan data pendukung seperti peta, tabel, gambar untuk memperjelas kondisi eksisting sarana dan prasarana tersebut. Setelah itu dalam penelitian ini melakukan metode analisis triangulasi. pemeriksanaan keabsahan data yang memanfaatkan sesuatu yang lain di luar data itu untuk keperluan pengecekan atau sebagai pembanding terhadap data itu.

Sampel yang menjadi subjek populasi dalam penelitian ini adalah orang-orang yang berpengaruh dalam pembangunan sarana dan prasarana yang ada di kawasan witasa Pantai Wonokerto Kabupaten Pekalongan sebagai narasumber antara lain Pemerintah, wisatawan dan pelaku usaha yang ada papa Kawasan witasa Pantai Wonokerto Kabupaten Pekalongan.

\section{GAMBARAN UMUM}

Ruang lingkup studi kawasan wisata pesisir Pantai Wonmokerto dengan luas kawasan penelitian $\pm 71 \mathrm{Ha}$. Kawasan wisata pesisir Desa Wonokerto Kulon dan Desa Tratebang mempunyai batas-batas kawasan: 
- Sebelah Utara $\quad$ : Laut Jawa

- Sebelah Timur : : Desa Api-Api

- Sebelah Selatan : : Sebagian Desa Tratebang

- Sebelah Barat : Desa Semut

Desa Wonokerto Kulon dan Desa Tratebang mempunyai kelas kelerengan 0-2\%, sehingga dengan kelas lereng tersebut merupakan daerah datar, beriklim tropis, dengan iklim mikro cukup lembab. Curah hujan di kawasan sama dengan curah hujan pada umumnya di Kecamatan Wonokerto, dengan rata- rata curah hujan mencapai $213 \mathrm{~mm} / \mathrm{thn}$. Keadaan suhu rata-rata $24-31^{\circ} \mathrm{C}$. Desa Wonokerto Kulon dan Desa Tratebang secara hidrologi dialiri oleh sungai utama yaitu Sungai Bedahan (Muara Baru) dengan lebar 6-8 meter di sebelah barat. Ciri penggunaan lahan yang ada Desa Wonokerto Kulon dan Desa Tratebang tersebut mempunyai pemanfaatan lahan campuran yang didominasi oleh permukiman, area pertambakan, tegalan dan area pantai. Kawasan permukiman penduduk yang merupakan permukiman nelayan terlihat masih sporadis dengan jumlah \pm 45 rumah. Jumlah penduduk di Penduduk Desa Wonokerto Kulon dan Desa Tratebang terdiri dari \pm 180 jiwa. Berdasarkan mata pencahariannya $80 \%$ penduduknya mempunyai mata pencaharian sebagai nelayan dengan proporsi jenis nelayan purse saine $20 \%$, nelayan santrang $30 \%$ dan nelayan arat $30 \%$. Selain nelayan, penduduk laki-laki mempunyai mata pencaharian sebagai petani tambak, buruh tambak, maupun buruh TPI. Sedangkan penduduk perempuan mempunyai mata pencaharian sebagai buruh batik, buruh TPI ataupun rumah tangga.

Terdapat berbagai potensi yang ada pada Kawasan wisata Pantai Wonokerto antara lain: adanya kampung nelayan beserta aktivitas nelayan di kawasan pesisir, terdapat Pantai Wonokerto yang mempunyai pasir pantai yang landai. Mempunyai dermaga kapal yang berfungsi sebagai tempat bersandar kapal-kapal milik nelayan, TPI yang cukup besar yaitu TPI Wonokerto di Muara Sungai Bedahan dengan semua komoditi unggulannya, kebun melati dan areal tambak. Selain itu pula terdapat kebudayaan, meliputi peninggalan bersejarah atau adat seperti kebudayaan sedekah bumi yang dilakukan setiap tahun dapat dijadikan sebagai kawasan pariwisata pesisir. Sedangkan permasalahan yang terjadi di Wisata Pesisir Pantai Wonokerto secara fisik adalah tidak tersedia dengan baiknya sarana prasana di Kawasan Pantai mulai dari kondisi jalan yang rusak dan terbatasnya tempat pembuangan sampah di sekitar pantai. Sedangkan permasalahan secara kelembagaan adalah kurang tertatanya sistem pengelolaan wisata pesisir. Hal ini terjadi disebabkan adanya tumpang tindih tanggung jawab dan kewenangan atas kawasan pesisir Pantai Wonokerto yang mengakibatkan pembangunan dalam pengembangan kawasan pesisir Pantai Wonokerto menjadi tidak optimal. 


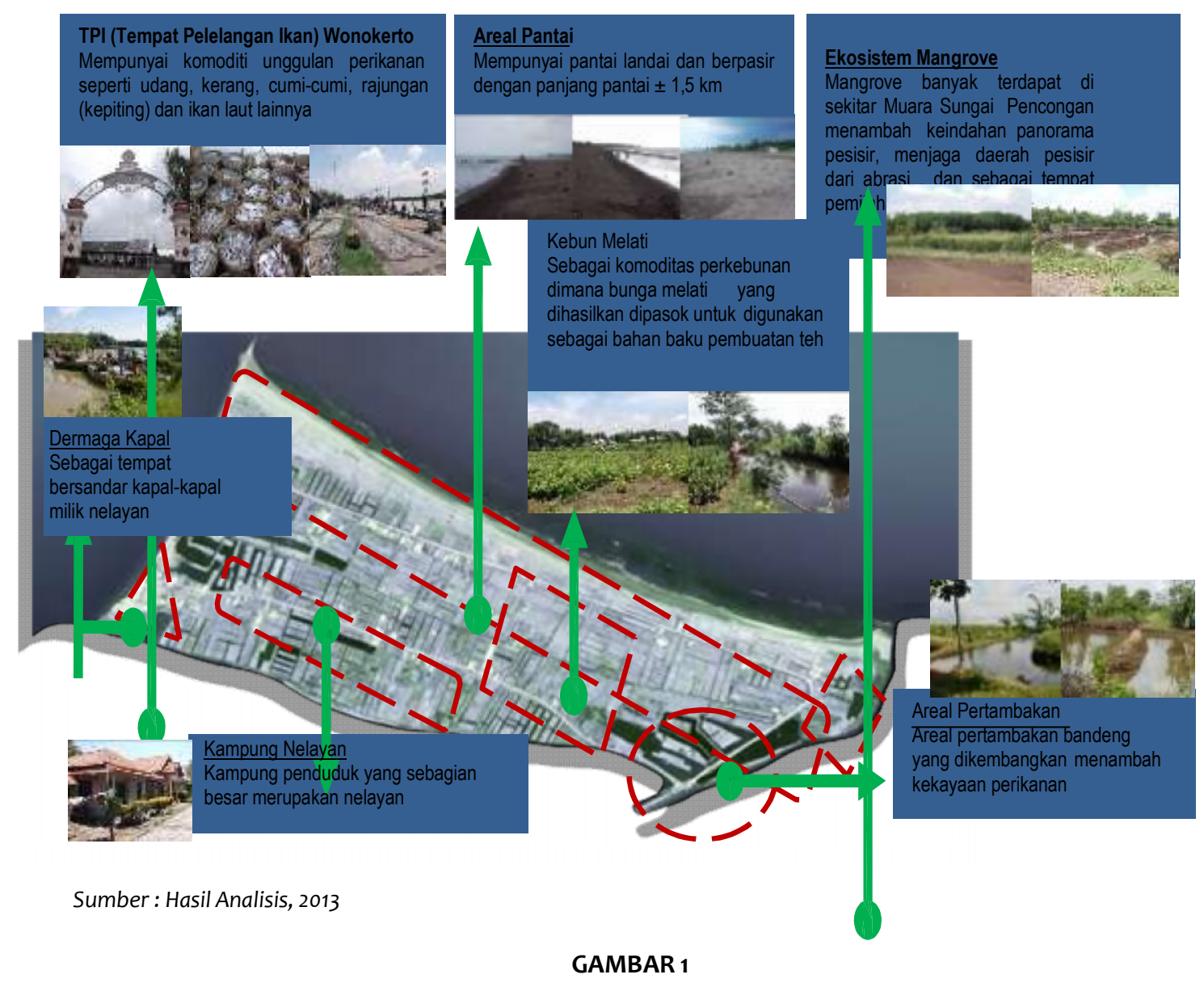

POTENSI KAWASAN WISATA PESISIR PANTAI WONOKERTO

\section{KAJIAN TEORI}

Pembangunan berkelanjutan dalam konteks pengelolaan pembangunan pesisir dan lautan secara teknis didefinisikan sebagai berikut: suatu upaya pemanfaatan sumberdaya alam dan jasa-jasa lingkungan yang terdapat di dalam kawasan pesisir dan lautan untuk kesejahteraan manusia (terutama stakeholders) sedemikian rupa, sehingga laju (tingkat) pemanfaatan sumberdaya alam dan jasa-jasa lingkungan termaksud tidak melebihi daya dukung (carrying capacity) kawasan pesisir dan lautan untuk menyediakannya (Dahuri, 2001). Menurut Liu et.al (2005), indikator pembangunan berkelanjutan untuk pembangunan kawasan pesisir terdiri dari 4 aspek yaitu :

1. Aspek ekologi diukur dari kondisi sumberdaya perikanan, komoditas utama perikanan, keberagaman sumberdaya perikanan, kualitas perairan, keragaman ekosistem, dan luas awasan konservasi.

2. Aspek ekonomi dapat dinilai dari jumlah tangkapan, nilai tangkapan, penerimaan bersih, jumlah tenaga kerja, banyaknya usaha perikanan, kuantitas kegiatan perikanan, investasi dan subsidi pemerintahan di bidang perikanan.

3. Aspek sosial dalam pengelolaan kawasan pesisir meliputi statistik dasar kependudukan dan tingkat pendidikan. Statistik dasar kependudukan terdiri dari tingkat kepadatan penduduk, ratio jenis kelamin, tingkat ketergantungan, tingkat kelahiran, tingkat pertumbuhan penduduk. Tingkat pendidikan terdiri dari angka melek huruf penduduk usia di atas 5 tahun, tingkat partisipasi sekolah, angka kecukupan tenaga pengajar 
dengan jumlah murid.

4. Aspek kelembagaan meliputi beberapa indikator yaitu efisiensi pengelolaan, tingkat partisipasi masyarakat, pengembangan kapasitas masyarakat, keberlanjutan kelembagaan.

Konsep pariwisata pesisir berkelanjutan (sustainable coastal tourism) adalah pariwisata yang dapat memenuhi kebutuhan wisatawan maupun daerah tujuan wisata pada masa kini, sekaligus melindungi dan mendorong kesempatan serupa dimasa yang akan datang. Pariwisata berkelanjutan mengarah pada pengelolaan seluruh sumberdaya sedemikian rupa sehingga kebutuhan ekonomi, sosial, estetika dapat terpenuhi sekaligus memelihara integritas kultural, proses ekologi essensial keanekaragaman hayati dan sistem pendukung kehidupan (WTO, 1980). Pengertian tersebut secara implisit menjelaskan bahwa dalam pendekatan pariwisata berkelanjutan bukan berarti hanya sektor pariwisata saja yang berkelanjutan tetapi berbagai aspek kehidupan dan sektor sosial ekonomi lainnya yang ada di suatu daerah (Butler, 1980). Pariwisata pesisir yang berkelanjutan adalah pariwisata yang dapat memenuhi kebutuhan generasi saat ini, tanpa mengorbankan kepentingan generasi yang akan datang untuk memenuhi kebutuhannya. Sarana dan prasarana wisata merupakan pelengkap daerah tujuan wisata yang diperlukan untuk melayani kebutuhan wisatawan dalam menikmati perjalanan wisatanya. Sarana pariwisata sebagai ujung tombak usaha kepariwisataan dapat diartikan sebagai usaha yang secara langsung maupun tidak langsung memberikan pelayanan kepada wisatawan pada suatu daerah tujuan wisata dimana keberadaannya sangat tergantung kepada adanya kegiatan perjalanan wisata. Adapun sarana tersebut adalah sebagai berikut :

a. Akomodasi

b. Tempat makan dan minum

c. Tempat belanja

d. Fasilitas umum di lokasi obyek wisata

Fasilitas umum yang akan dikaji adalah fasilitas yang biasanya tersedia di tempat rekreasi seperti :

- Tempat parkir

- WC umum

- Mushola/masjid

- Sarana penggerak di lokasi obyek wisata

- Sarana informasi dan papan petunjuk

- Sarana rekreasi dan taman bermain

- Telepon umum

\section{ANALISIS FISIK KAMPUNG PEKOJAN}

Sarana dan prasarana merupakan hal yang penting dalam suatu kegiatan pembangunan, penyediaan sarana dan prasarana yang sesuai dengan kebutuhan akan berguna dalam kegiatan pembangunan tersebut.

Dalam konteks pariwisata, harus dipahami pengertian sarana dan prasarana agar penyediaan sarana dan prasarana mendukung kegiatan pariwisata yang berkelanjutan.Untuk mengetahui hal tersebut maka dilakukan beberapa analisis antara lain :

\section{Analisis Tautan Wilayah Kawasan Pesisir Pantai Wonokerto terhadap Lingkungan Sekitarnya}

Pemerintah Kabupaten Pekalongan yang memiliki misi untuk mengembangkan pariwisata dan budaya lokal. Kebijakan fungsi tersebut akan diarahkan pada upaya pengembangan 
pariwisata dengan meningkatkan kualitas kepariwisataan dan perbaikan sarana dan prasarana yang ada, tanpa meninggalkan upaya pemasaran pariwisata kepada masyarakat luas dan para penanam modal secara intensif dan berkelanjutan. Dalam pengembangan budaya lokal difungsikan sebagai bentuk pengembangan, pemererat dan pelestarian budaya lokal yang bertujuan untuk membentuk masyarakat Kabupaten Pekalongan yang berkarakteristik. Kawasan Pesisir Wonokerto memiliki tautan yang cukup besar terhadap wilayah sekitarnya. Kawasan ini juga merupan alternatif berlibur bagi masyarakat. Baik hari libur akhir pekan maupun hari libur besar atau nasional. Hal ini didukung pula dengan adanya TPI dimana masyarakat dapat membeli ikan segar, masyarakat yang datang untuk membeli tidak hanya dari daerah Wonokerto saja tetapi sampai masyarakat luar Wonokerto atau terkadang dari luar kota. Belum lagi dataran pantai yang setiap tahun bukannya mengalami abrasi melain akresi yaitu penambahan luasan daratan. Dengan demikian jika tidak dikelola dan disediakan sarana dan prasarana yang baik dan memadai maka daerah kawasan ini tidak dapat berkembang secara optimal.

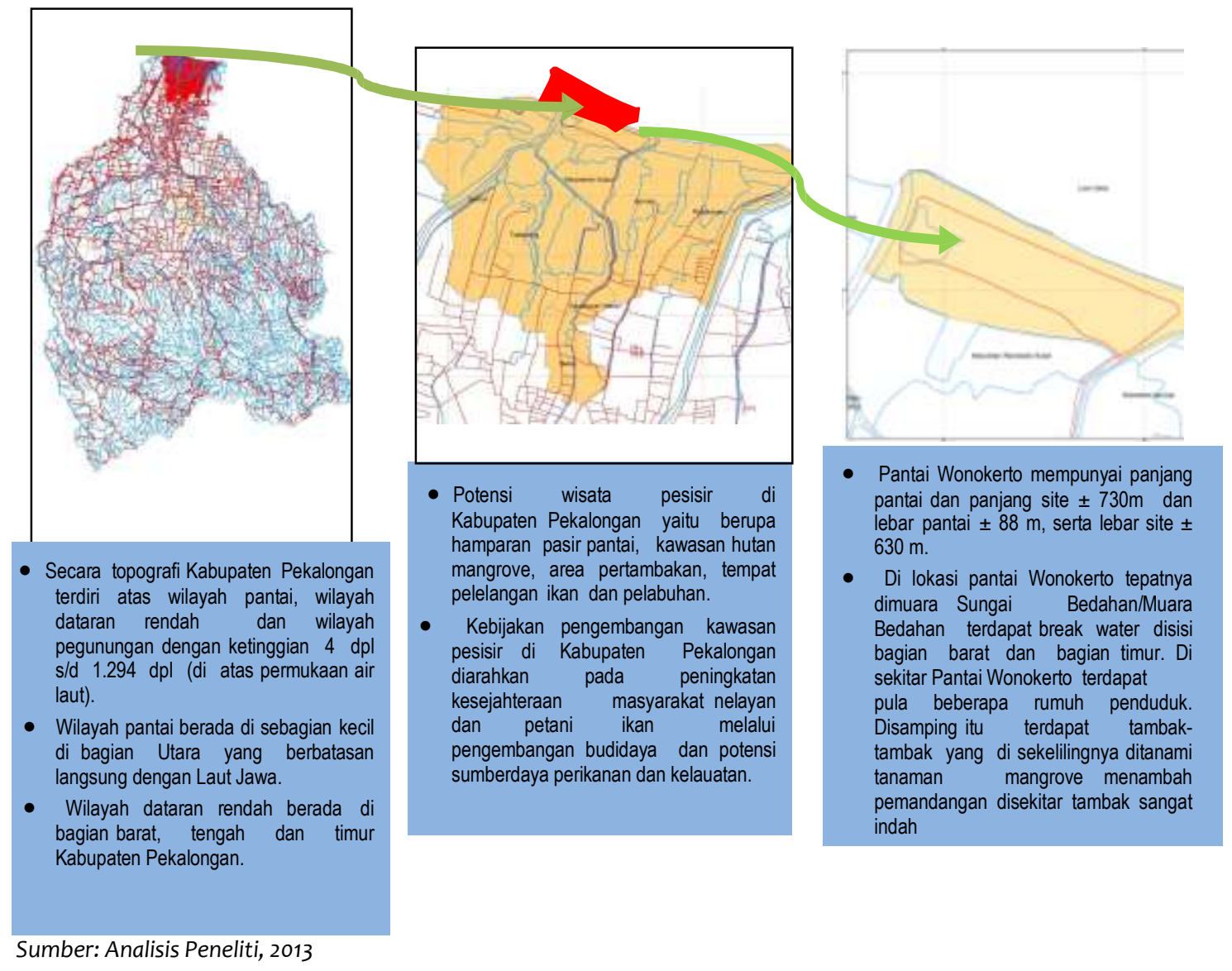

GAMBAR 3

TAUTAN WILAYAH KAWASAN PESISIR PANTAI WONOKERTO TERHADAP LINGKUNGAN SEKITARNYA

\section{Analisis Jumlah, Sebaran dan Kondisi Sarana dan Prasarana Pariwisata Pesisir yang Berkelanjutan di Pantai Wonokerto Kabupaten Pekalongan}

2.1. Analisis ketersediaan kelengkapan sarana dan prasaran rekreasi Wisata Pantai Wonokerto (Supply of Faciliities) 


\section{Akomodasi}

Pada kawasan pesisir Pantai Wonokerto akomodasi yang ada pada kawasan masih sangat kurang bahkan mungkin bisa dikatakan tidak ada. Karena akomodasi yang ada berada cukup jauh dengan tempat wisata yang disediakan. Walaupun beberapa tempat akomodasi sudah bisa dikatakan layak dengan fasilitas yang diberikan. Hal ini juga merupakan faktor penting jika kawasan ini akan melakukan pembangunan, sebab pada dasarnya wisatawan akan memerlukan tempat tinggal untuk sementara waktu selama dalam perjalanan untuk dapat beristirahat. Dengan adanya sarana ini, maka akan mendorong wisatawan untuk berkunjung dan menikmati objek dan daya tarik wisata dengan waktu yang relatif lebih lama. Informasi mengenai akomodasi ini mempengaruhi penilaian wisatawan pilihan jenis akomodasi yang dipilih, seperti jenis fasilitas dan pelayanan yang diberikan, tingkat harga, jumlah kamar yang tersedia dan sebagainya.

2. Tempat makan dan minum

Pada dasarnya wisatawan yang datang berkunjung ke suatu objek wisata tentunya ingin menikmati perjalanan wisatanya, sehingga pelayanan makanan dan minuman harus mendukung hal tersebut bagi wisatawan yang tidak membawa bekal. Bahkan apabila suatu daerah tujuan wisata mempunyai makanan yang khas, wisatawan yang datang disamping menikmati atraksi wisata juga menikmati makanan khas tersebut. Begitu pula yang ada pada kawasan Pantai Wonokerto masyarakat yang datang tidak hanya menikmati atraksi yang ada. Rata-rata yang datang sambil menikmati atraksi yang ada wisatawan pun ikut menikmati makanan yang di jual atau yang mereka bawa sendiri dari rumah. Untuk fasilitas makanan dan minuman yang ada pada kawasan ini masih kurang baik dari segi jenis dan variasi makanan yang ditawarkan, tingkat kualitas makanan dan minuman, pelayanan yang diberikan, tingkat harga, tingkat higienis, dan hal-hal lain yang dapat menambah selera makan seseorang serta lokasi tempat makannya. Memang makanan yang sudah ada mulai dari makanan berat seperti makanan pokok (nasi dan lauk pauk) sampai dengan makanan ringan (jajanan) tetapi masih dikatakan kurang jika direncanakan secara berkelanjutan. Selain fasilitasnya yang masih kurang, pembuangan limbah tersebut juga belum terkelola dengan baik dan benar sehingga bisa menimbulkan pencemaran lingkungan jika dibiarkan berlarut-larut.

3. Tempat belanja

Berbelanja merupakan salah satu aktivitas kegiatan wisata dan sebagian pengeluaran wisatawan didistribusikan untuk berbelanja. Berbelanja dalam konteks ini bukan merupakan tempat makanan dan minuman melainkan tempat wisatawan membeli oleh-oleh khas kawasan wisata untuk menandakan bahwa wisatawan pernah datang berkunjung ke wisata ini. Di kawasan pesisir Pantai Wonokerto belum ada tempat khusus yang menjajakan oleh-oleh khas daerah sehingga wiasatawan yang datang tidak bisa membelanjakan uang mereka. Padahal tersedia barang-barang untuk dijual seperti kerajinan kerang atau makanan olahan khas kawasan pesisir Pantai Wonokerto. Pada akhinya barang-barang tersebut dijual diluar kawasan pesisir Pantai Wonokerto seperti ditengah kota atau pasar-pasar terdekat. Secara ekonomi hal ini bisa merugikan perekonomian daerah, dimana seharusnya uang yang beredar tidak keluar tetapi tetap berputar di dalam daerah dan bahkan dapat meningkatkan pendapatan daerah. Hal ini juga dapat menjadi alternatif bagi para wisatawan dalam membelanjakan uangnya. Wisatawan bisa berbelanja barang kenangkenangan berupa barang bukan hanya ikan di TPI.

4. Fasilitas umum di lokasi objek wisata

Tidak beda jauh dengan fasilitas yang lainnya fasilitas umum yang ada di 
kawasan pesisir Pantai Wonokerto juga belum semuanya tersedia dan kalaupun ada masih jauh dari kata layak, seperti:
a. Tempat parkir
b. Tempat MCK umum
c. Sarana Peribadatan
d. Sarana penggerak di lokasi obyek wisata
e. Sarana informasi dan papan petunjuk
f. Sarana rekreasi dan taman bermain
g. Jaringan Listrik dan Telekomunikasi

2.2. Analisis permintaan/kebutuhan kelengkapan sarana dan prasarana rekreasi Wisata Pantai Wonokerto (Demand for Recreation)

1. Akomodasi

Untuk menarik wisatawan berkunjung semakin banyak dan dalam waktu yang lama, dibutuhkan akomodasi yang nyaman dan aman. Seperti tempat tinggal untuk sementara waktu selama dalam perjalanan untuk dapat beristirahat. Dengan adanya sarana ini, maka akan mendorong wisatawan untuk berkunjung dan menikmati objek dan daya tarik wisata dengan waktu yang relatif lebih lama. Sarana akomodasi yang diinginkan oleh wisatawan juga selain fasilitas yang aman dan nyaman, sarana tersebut juga berada pada kawasan wisata pesisir Pantai Wonokerto tersebut. Hal ini disebabkan, keinginan wisatawan untuk tinggal dikawasan wisata agar dapat menikmati atraksi yang ada pada kawasan tidak hanya pada siang hari tetapi juga dapat dilakukan pada malam hari.

2. Tempat makan dan minum

Rata-rata permintaan atau kebutuhan wisatawan akan tempat makan dan minum pada kawasan pesisir Pantai Wonokerto hanya menginginkan tempat yang bersih, aman dan nyaman dengan harga yang terjangkau. Untuk kualitas dari makanan atau minuman yang dijual baik. Jenis atau variasi makanan dan minuman juga diutamakan agar wisatawan dapat membeli sesuai dengan selera mereka masingmasing. Untuk meningkatkan daya tarik kawasan juga disediakan makanan khas daerah seperti Gulai Kepala Mayun, Nasi Megono, Soto Tauco atau Pindang Tetel untuk makanan pokoknya, sedangkan makanan ringan seperti Kerupuk Tahu dan Kuping Gajah. Sehingga para wisatawan dapat merasakan makanan khas daerah tersebut. Tempat makan dan minum diharapkan berada berdekatan dengan tempat belanja dan jaraknya berada dalam kawasan wisata. Hal ini agar para wisatawan dengan mudah mencapainya, selain itu pula wisatawan dapat sambil beristirahat makan juga dapat melihat atau bahkan berbelanja kenang-kenangan khas daerah.

3. Tempat belanja

Pada dasarnya manusia jika melakukan perjalanan pasti akan berbelanja sebagai buah tangan atau sebagai kenang-kenangan tanda bukti bahwa mereka pernah mengunjungi tempat tersebut. Dengan demikian ini merupakan kesempatan daerah untuk manaikan pendapatan daerah, memperkenalkan aset daerah dan meningkatkan pendapatan masyarakat setempat. Hal ini dilakukan dengan cara menjajakan hasil karya penduduk asli. Tetapi untuk itu harus menyediakan tempat berbelanja pada kawasan pesisir Pantai Wonokerto. Dalam perencanaan dan pembangunannya tempat berbelanja tersebut haruslah berkelanjutan tidak hanya yang penting ada atau dibangun tanpa ada perencanaan dalam pembangunannya. Pembangunan yang dilakukan dengan tetap mengutamakan kenyamanan dan keamanan bagi para pembeli nanti. 


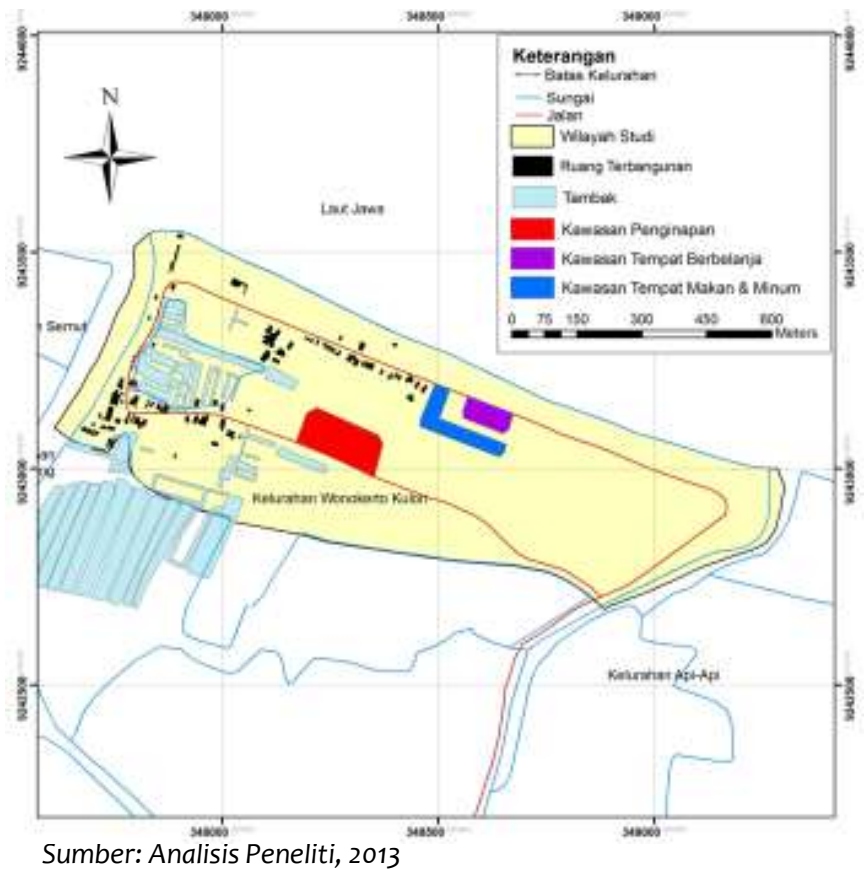

GAMBAR 4

PETA ANALISIS AKOMODASI, TEMPAT BERBELANJA, TEMPAT MAKAN DAN MINUM KAWASAN WISATA PESISIR PANTAI WONOKERTO

4. Fasilitas umum di lokasi objek wisata

Fasilitas umum yang tersedia pada kawasan pesisir Pantai Wonokerto pada umumnya harus mengalami peningkatan baik secara kualitas dan kuantitas karena hal ini penting untuk menunjang aktifitas para wiasatawan yang datang. Fasilitas itu antara lain:

a. Tempat parkir

Harus ada tempat khusus untuk parkir. Agar wisatawan yang datang berkunjung ke kawasan wisata dapat meninggalkan kendaraan mereka dengan merasa aman dan nyaman. Tempat parkir yang disediakan harus terencana dan dikelola dengan baik agar tempat parkir itu berkelanjutan dan dapat memberikan penghasilan yang lebih bagi daerah.

b. Tempat MCK umum

Harus tersedianya tempat MCK umum bagi wisatawan yang datang untuk berkunjung. Dengan keadaan yang aman dan nyaman, bersih dan mudah dijangkau. Untuk itu pembangunan MCK umum dibangun dibeberapa titik dengan jumlah yang cukup banyak. 4 pintu tempat MCK umum dengan luas $2 \times 2$ di sekitar TPI dan 8 pintu tempat MCK umum dengan luas $2 \times 2$ di sekitar pantai. Sehingga wisatawan dengan mudah mencapai tempat MCK umum.

c. Sarana Peribadatan

Pada dasarnya sarana peribadatan yang ada sudah tersedia, hanya saja sarana tersebut masih banyak yang harus diperbaiki. Baik dari luasan, kebersihan maupun sarana penunjang dari tempat peribadatan tersebut, seperti air bersih dan perangkat ibadah. Karena lokasi tempat peribadatan tidak berada ditengahtengah kawasan maka diharapkan ada tempat peribadatan berdekatan dengan pantai agar wisatawan yang datang dapat beribadah dengan mudah. 
d. Sarana penggerak di lokasi obyek wisata

Sarana penggerak yang diingikan hanya berupa sarana transportasi yang nyaman, aman dan murah. Wisatawan tidak kesulitan dalam menjangkaunya. Wisatawan juga menginginkan sarana untuk berjalan kaki yang nyaman dimana sepanjang ruas jalan di tumbuhi tumbuhan peneduh, terdapat tempat beristirahat jika merasa lelah dan tempat membuang sampah. Agar ketika wisatawan yang berjalan kaki sambil minum atau makan mereka tidak akan membuang sampahnya secara sembarangan dan sepanjang jalan akan bersih dan nyaman.

e. Sarana informasi dan papan petunjuk

Papan petunjuk atau informasi tentang kawasan pesisir Pantai Wonokerto ini diharapkan, tidak hanya satu pada pintu utama jalan masuk tetapi juga terdapat pengumuman atau baleho iklan kawasan pesisir disetiap kawasan stategis. Tidak hanya itu, dalam menginformasikan kawasan juga dilakukan pada iklan di koran, radio ataupun majalah. Pada kawasan wisata juga harus tersedia sarana informasi dan papan petunjuk. Hal ini dilakukan guna wisatawan yang adatang dapat dengan mudah mencapai atraksi yang mereka inginkan.

f. Sarana rekreasi dan taman bermain

Sekarang ini sarana rekreasi dan taman bermain pada kawasan Pantai Wonokerto memang tidak ada, tetapi melihat kodisi eksisting, memungkinkan untuk dapat membangun sarana rekreasi dan taman bermain. Sarana yang dibangun diharapkan sarana rekreasi dan taman bermain yang menarik aman dan nyaman tanpa merusak atraksi yang ada pada kawasan wisata. Sehingga wisatawan semakin banyak tempat pilihan untuk berwisata dan membuat mereka semakin lama berwisata di sana.

g. Jaringan Listrik dan Telekomunikasi

Dari semua fasilitas penunjang wisata, hanya jaringan listrik dan telekomunikasi yang paling baik. Hanya saja, penerangan pada kawasan pesisir Pantai Wonokerto masih sangat minim sehingga masih banyak tempat-tempat yang gelap. Hal ini mengundang kriminalitas dilakukan. Untuk mengantisipasi hal tersebut, diharapkan pada kawasan pesisir Pantai Wonokerto baik sepanjang jalan dan setiap tempat wisata atraksi terdapat penerangan. Deangan demikian wisatawan dapat menikmati atraksi yang ada tidak hanya pada siang hari, malam hari juga.

h. Persampahan

Tempat pembuangan sampah juga ditingkatkan baik jumlah tempat sampahnnya maupun kualitasnya. Peletakannya juga diharapkan sesuai dengan kebutuhan wisatawan dalam menujang aktifitas wisata yang mereka lakukan. Kawasan juga tidak akan terlihat kumuh jika sampah yang ada sudah tertangani dengan baik dan dipisahkan antara sampah organik dan sampah anorganik. Pada kawasan wisata pesisir Pantai Wonokerto sampah yang terkumpul akan diambil mobil sampah dalam periode tertentu.

i. Jaringan drainase dan sanitasi

Perbaikan jaringan drainase dan sanitasi sangat diharapkan guna mengantisipasi banjir yang terjadi jika penghujan datang maupun air laut pasang (rob). Peningkatan kualitas dan kuantitas dari fasilitas umum ini diharapkan wisatawan yang datang akan senang dan kembali lagi untuk berlibur di kawasan pesisir Pantai Wonokerto ini. 


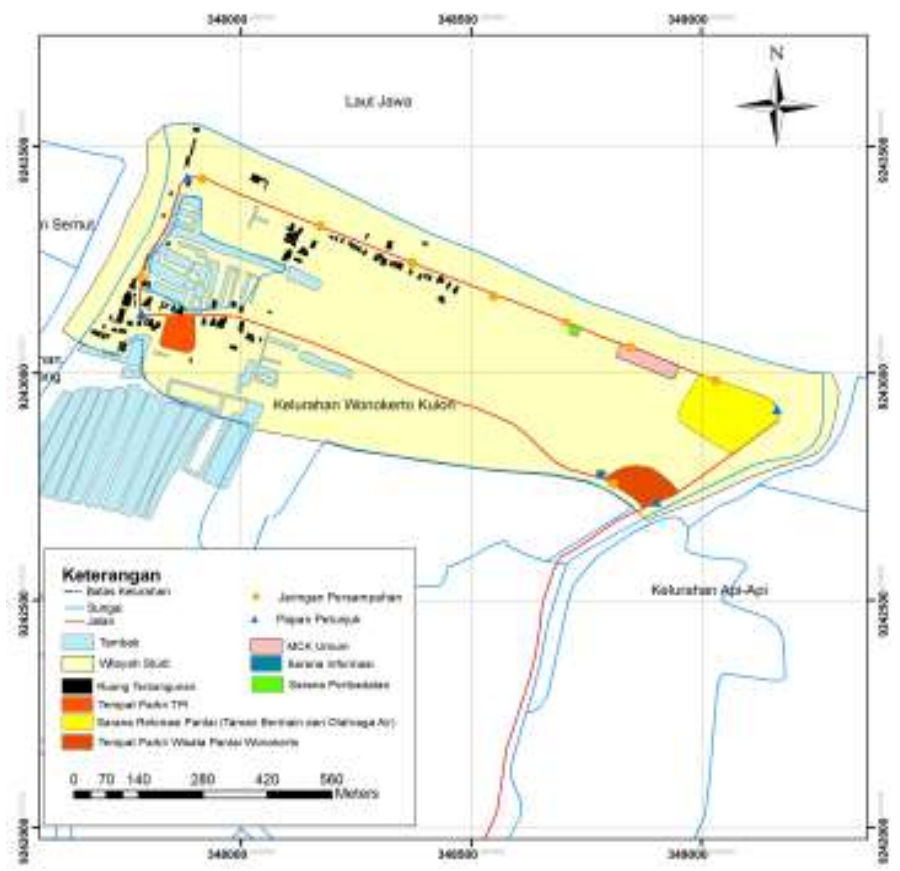

Sumber: Analisis Peneliti, 2013

\section{GAMBAR 5 \\ PETA ANALISIS FASILITAS UMUM KAWASAN WISATA PESISIR PANTAI WONOKERTO}

Analisis Pendekatan kepada Pengguna/Wisatawan Sarana dan Prasarana Pariwisata Pesisir y ang Berkelanjutan di Pantai Wonokerto Kabupaten Pekalongan

3.1. Analisis daya tarik Wisata Pantai Wonokerto Kabupaten Pekalongan terhadap sosial, ekonomi dan lingkungan

Pada kawasan Pantai Wonokerto memiliki berbagai macam daya tarik untuk menarik wisatawan untuk berkunjung ke kawasan pesisir ini. Dengan berdatangannya para wisatawan pada kawasan pesisir Pantai Wonokerto, hal ini mempengaruhi dari sisi sosial, ekonomi dan lingkungan. Antara lain:

1. Atraksi

Atraksi yang terdapat pada kawasan pesisir Pantai Wonokerto merupakan objek wisata yang memberikan kenikmatan kepada wisatawan yang datang berkunjung. Pada kawasan ini terdapat dua jenis atraksi yang disediakan, antara lain:

a. Wisata alam, kegiatan wisata alam meliputi pemandangan alam yang dalam hal ini pemandangan pantai, perkebunan melati, TPI (Tempat Pelelangan Ikan)

b. Wisata budaya, meliputi peninggalan bersejarah atau adat seperti kebudayaan sedekah bumi yang dilakukan setiap tahun.

Atraksi yang terdapat pada kawasan pesisir Pantai Wonokerto membutuhkan ruang dalam melaksakan semua atraksi. Ruang tersebut jika tidak di rencanakan dan dikelola dengan baik maka dapat merusak lingkungan atau bahkan dapat merusak atraksi itu sendiri. Atraksi yang terdapat pada kawasan pesisir Pantai Wonokerto jika dioptimalkan dapat memberikan peluangkerja bagi masyarakat pribumi yang ada pada kawasan pesisir Pantai Wonokerto. 
2. Amenity (Pelayanan atau Kelembagaan)

Karena kawasan pesisir Pantai Wonokerto masih belum terkelola dengan baik maka secara pelayanan dan kelembagaannya masih sangat kurang dan perlu diadakannya perbaikan. Padahal jika pelayanan itu diadakan dengan sangat baik bisa menjadi motor penggerak yang kuat dalam perkembangan sistem kepariwisataan pada kawasan pesisir Pantai Wonokerto. Karena dengan pelayanan yang baik maka wisatawan yang datang akan melakukan perilaku yang baik pula. Secara tidak langsung semua stakeholders yang terkait menjaga kelestarian lingkungan, sosial dan budaya. Dengan demikian wisatawan yang datang akan meningkat jumlahnya begitu pula dengan perekonomian yang ada pada daerah secara tidak langsung maka pendapatan perekonomian daerah akan meningkat.

3. Aksesibilitas

Pada kawasan pesisir Pantai Wonokerto dari berbagai macam potensi yang ada pada kawasan, untuk mengakses tempat tersebut masih kurang baik. Untuk wisatawan yang tidak memiliki kendaraan pribadi masih sangat sulit untuk menjangkaunya karena belum tersedia angkutan umum untuk mencapai tempat tersebut. Hal ini yang menjadi salah satu kendala dalam mengoptimalkan pariwisata yang ada pada kawasan pesisir Pantai Wonokerto. Kondisi jalan yang rusak dan sempit mengakibatkan sulitnya wisatawan untuk mengakses wisata tersebut. Wisatawan yang ingin mengakses kawasan pesisir Pantai Wonokerto ini hanya dapat menggunakan dokar atau kertakeretaan yang memutar satu jam sekali atau berjalan kaki. Padahal jika bisa dikelola dengan baik, maka dapat menguntungkan semua pihak. Mulai dari wisatawan yang naik atau para penyedia jasa angkutan umum dalam mengakses kawasan pesisir Pantai Wonokerto. Para wisatawan dengan mudahnya mengakses kawasan pesisir Pantai Wonokerto sedangkan para penyedia jasa dapat keuntungan dari penjualan jasa mereka dan bisa meningkatkan pendapatan perekonomian mereka.

4. Promosi

Promosi yang dilakukan untuk mempromosikan kawasan pesisir Pantai Wonokerto masih sangat minim belum optimal. Dalam perhitungan finansial promosi ini memang akan memerlukan biaya yang banyak sebagai modal tetapi secara ekonomi ini akan sangat menguntungkan dan bisa jangka panjang atau berkelanjutan. Promosi itu sendiri perlu dilakukan karena untuk menjaring infestor agar menanam saham pada kawasan pesisir Pantai Wonokerto. Dengan datangnya infestor maka pembangunan yang lebih baik dan nyaman akan terlaksanakan dengan mempertimbangkan lingkungan yang ada. Pada akhirnya roda perekonomian akan terus berjalan dan meningkatkan pendapatan daerah. Promosi yang dilakukan bisa dengan lewat radio, televisi atau dalam bentuk tertulis (spanduk, koran, majalah dan lain sebagainya).

3.2. Analisis pengaruh daya tarik pengunjung terhadap kelengkapan sarana dan prasarana Wisata Pantai Wonokerto Kabupaten Pekalongan.

Daya tarik wisata adalah suatu bentukan dan atau aktifitas dan fasilitas yang berhubungan, yang dapat menarik minat wisatawan atau pengunjung untuk datang kesuatu daerah/tempat tertentu. Daya tarik pengunjung sangat penting terhadap suatu kawasan wisata. Karena pada dasarnya menarik atau tidaknya suatu kawasan witasa dapat dilihat dari daya tarik pengunjung yang datang pada kawasan wisata. Dengan begitu besar pengaruh daya tarik pengunjung terhadap kelengkapan fasilitas sarana dan prasarana pariwisata. Karena wisatawan akan menjadi kurang tertarik pada suatu kawasan wisata jika kawasan tersebut tidak memiliki daya tarik yang sesuai dengan daya tarik wisatawan terutama dalam pemenuhan saran dan prasarananya. Untuk itu sarana dan prasarana yang ada harus dibangun pada kawasan pesisir Pantai Wonokerto harus sesuai dengan 
kebutuhan wisata, agar wisatawan yang datang terkesan dan senang. Dengan begitu wisatawan yang sudah datang akan kembali lagi untuk menikmati liburannya. Tetapi jika sarana dan prasarana yang dibangun tidak sesuai dengan yang diharapkan wisatawan, kemungkinan besar wisatawan tersebut tidak akan kembali datang untuk yang kedua kalinya. Karena daya tarik pengunjung atau wisatawan tidak ada sehingga mereka akan memilih tempat yang lebih menarik. Oleh karena itu, suatu daya tarik dapat dimanfaatkan sebagai daya tarik wisata. Untuk mengatasi hal tersebut maka dalam pembangunan sarana dan prasarana guna memfasilitasi para wisatawan maka bangunan harus disesuaikan dengan kebutuhan daya tarik wisatawan dengan mempertimbangkan aspek lingkungan agar dapat berkelanjutan.

\section{Analisis Pengembangan Sarana dan Prasarana untuk Mendukung Pariwisata Pantai yang Berkelanjutan}

1. Aspek Sosial

Dengan banyaknya wisatawan yang datang selama ini dengan pendidikan masyarakat pribumi yang masih dibawah rata-rata maka dampak yang ditimbulkan oleh kegiatan pariwisata disuatu daerah terhadap sosial budaya sangat terasa apalagi daerah tersebut menerima pengaruh dengan cepat tanpa ada penyaringan yang ketat terhadap kedatangan wisatawan. Masalah tentang dampak pariwisata terhadap sosial budaya selama ini lebih cenderung akan terjadi perubahan sosial-budaya akibat kedatangan wisatawan. Dalam pengembangan sarana dan prasarana diharapkan penduduk asli dapat memanfaatkan untuk meningkatkan pengetahuan, kesadaran akan pemeliharaan, sehingga potensi dan semua sarana dan prasarana penujang aktifitas berwisata dapat berkelanjutan.

2. Aspek Ekonomi

Perekonomian yang ada pada kawasan wisata pesisir Pantai Wonokerto masih bisa dikatakan belum optimal karena dengan berbagai potensi yang masyarakat masih mengandalkan dari bernelayan saja. Sehingga pendapatan mereka tidak terlalu besar walaupun setiap tahun mengalami peningkatan. Peningkatan tersebut juga tidak terlalu signifikan tidak sesuai dengan potensi yang pada kawasan wisata pesisir Pantai Wonokerto yang kurang lebih hanya $5 \%$ saja. Dengan pengembangan sarana dan prasarana pariwisata yang berkelanjutan masyarakat diharapkan dapat mengoptimalkan hal tersebut. Dengan cara mengajak organisasi lokal untuk meningkatkan kesejahteraan masyarakat melalui aktivitas ekonomi seperti koperasi, pengembangan Usaha Kecil Menengah (UKM) dalam berbagai usaha kerajinan, makanan, minuman, perdagangan, pertanian dan lain-lain sehingga mereka akan banyak memperoleh manfaat dari pengembangan sarana dan prasarana pariwisata, khususnya dikawasan wisata Pantai Wonokerto. Dengan demikian maka perekonomian akan menjadi lebih baik tidak hanya bergantung dari bernelayan dan berkesinambungan karena tetap menjaga wisata agar berkelanjutan.

3. Aspek Lingkungan

Kegiatan pariwisata cenderung merusak kelestarian lingkungan alam dan budaya setempat, oleh karenanya perlu dijaga agar terhindar dari dampak negatif dengan pengawasan dan pengendalian yang ketat, memperhatiakan dan mencerminkan ciri budaya setempat yang khas. Dengan demikian, pengembangan sarana dan prasarana di harapkan dapat mendukung pariwisata pantai dan bisa meminimalisir pencemaran lingkungan yang terjadi. Dimana lingkungan yang awalnya masih belum tertata dengan baik dengan pengembangan sarana dan prasarana secara tidak langsung akan mengalami perubahan menjadi terencana. Pengembangan tersebut akan membuat sarana dan prasarana pariwisata yang tidak ada menjadi ada pada kawasan tersebut dengan mengoptimalkan lingkungan wisata pantai guna memfasilitasi aktifitas wisatawan yang datang tanpa 
merusak lingkungan.

4. Aspek Kelembagaan

Berdasarkan hasil survey yang dilakukan pada kawasan wisata pesisir Pantai Wonokerto masih belum terdapat kelembagaan untuk mengelola pariwisata yang ada. Belum adanya singkronisasi antara instansi yang terkait juga menambah masalah terhadap pengelolaan kawasan wisata Pantai Wonokerto. Hal ini mengakibatkan sarana dan prasarana yang telah disediakan tidak terawat bahkan tidak tersedia. Jika kawasan wisata pesisir Pantai Wonokerto ini ingin berkenjutan, maka sangat diperlukan organisasi untuk mengelola. Dalam pengelolaan dan pemeliharaan kawasan wisata pesisir Pantai Wonokerto dengan cara menggabungkan kerjasama antara pemerintah dan swasta (Public Private Partnership) dan dengan melibatkan masyarakat. Hal ini dilakukan agar semua potensi yang ada dapat teroptimalkan dan tanpa merusak lingkungan sehingga tetap dapat dinikmati dimasa yang akan datang.

\section{Analisis Pendekatan Kebijakan Pemerintah Mengenai Pembangunan Sarana dan Prasarana} Pariwisata Pesisir yang Berkelanjutan di Pantai Wonokerto Kabupaten Pekalongan

Kebijakan daerah Kabupaten Pekalongan terhadap kawasan pesisir Pantai Wonokerto masih dinilai mendukung perkembangan kawasan. Terutama untuk sebagai kawasan wisata pesisir. Walaupun dalam RTRW, Peraturan Daerah Kabupaten Pekalongan Nomor 17 Tahun 2009 Tentang Rencana Zonasi Wilayah Pesisir dan Peraturan Daerah Kabupaten Pekalongan Nomor 16 Tahun 2009 Tentang Pengelolaan Wilayah Pesisir disebutkan bahwa Kawasan pesisir pantai Wonokerto akan diarahkan sebagai pengembangan kegiatan perekonomian yang bersifat perairan baik perikanan laut maupun perikanan darat. Selain penangkapan ikan dan pertanian ikan juga diarahkan bagi pengembangan pengolahan ikan seperti pengalengan ikan dan pembekuan ikan. Disamping itu, Kecamatan Wonokerto akan diarahkan sebagai pusat pengembangan kegiatan wisata alam. Pemerintah Daerah Kabupaten Pekalongan masih belum menetapkan suatu pelaksana teknis yang formal dalam pengelolaan pariwisata. Namun dalam pengelolaan kawasan pesisir pantai Wonokerto secara implisit beberapa stakeholder pemerintah sudah terlibat aktif dalam pengambangan kawasan pesisir tersebut. Bukti keseriusan pemerintah daerah Kabupaten Pekalongan dalam pengembangan pariwisata pesisir pantai Wonokerto adalah dengan disusunnya Dokumen Masterplan Khusus Pariwisata Kawasan Wonokerto. Dalam dokumen tersebut dijabarkan mengenai rencana pengembangan pariwisata di kawasan Wonokerto. Dokumen tersebut disusun dengan dimotori oleh Dinas Pemuda, Olahraga dan Pariwisata. Tetapi dalam pengembangannya setelah semua dokumen yang ada terbuat, tidak ada satupun program yang dilaksanakan pada kawasan pesisir pantai Wonokerto bahkan terkesan dibiarkan saja. Sehingga sampai saat ini kawasan pesisir pantai Wonokerto masih belum ada pengelolaan yang baik guna mengembangkan potensi yang ada.

\section{KESIMPULAN}

Berdasarkan hasil analisis yang dilakukan kawasan wisata pesisir Pantai Wonokerto memiliki banyak potensi tetapi sarana dan prasarana pendukung aktifitas wisata masih membutuhkan peningkatan kualitas maupun kuantitasnya. Pembangunan Sarana dan Prasarana Pariwisata Pesisir yang berkelanjutan harus berpedoman dengan empat elemen penting yang menjadi acuan dalam teori keberlanjutan yaitu: aspek sosial dimana dibutuhkan peningkatan kesadaran akan pemeliharaan, diberikan pengetahuan dan melibatkan penduduk asli dalam engembangan sarana dan prasarana untuk menunjang aktifitas pariwisata pantai yang berkelanjutan, aspek ekonomi pengembangan sarana dan prasarana 
pariwisata untuk mendukung pariwisata pantai maka secara tidak langsung menarik wisatawan berkunjung, mengajak organisasi lokal untuk meningkatkan kesejahteraan masyarakat melalui aktivitas ekonomi, aspek lingkungan dibutuhkan kesadaran bahwa pemanfaatan sumber daya manusia dan alam secara berlebihan akan mengganggu keseimbangan lingkungan dan aspek kelembagaan. Diperlukannya pengelolaan dan pemeliharaan kawasan wisata pesisir Pantai Wonokerto dengan cara menggabungkan kerjasama antara pemerintah dan swasta dan dengan melibatkan masyarakat. Keempat elemen ini harus bersinergi agar tidak pincang dan menimbulkan masalah di generasi selanjutnya. Hal ini dapat dirumuskan rekomendasi bagi pemerintah terutama berupa pengembangan daerah yang berkaitan dengan sarana dan prasarana dan partisipasi masyarakat dalam proses pelaksanaannya untuk menjaga kelestarian kawasan wisata Pantai Wonokerto.

\section{DAFTAR PUSTAKA}

Butler. R.W. 1980. The Concept of Tourism Area Cycle of Evolution: Implications for the Management of resources. The Canadian Geographer.

Dahuri R, Rais J, Ginting SP dan Sitepu MJ. 2001. Pengelolaan Sumberdaya Pesisir dan Lautan Secara Terpadu. PT. Pradnya Paramita. Jakarta.

Gun, Clare A. 2002. Tourism Planning Basics, Concepts, Cases. New York: Routledge Taylor \& Francis.

Liu, Pang-Lo, Wen-Chin Chen, \& Chih-Hung Tsai. 2005. "An Empirical Study on The Correlation between The Knowledge Mana-gement Method and New Product Develop-ment Strategy on Product Performance in Taiwan"s Industries", Technovation.

Nazir, Moh. 2003. Metode Penelitian. Jakarta: Ghalia Indonesia. Of Planning. Univercity College London, Vol 10. No 3, 309-330, Oktober 2005.

WTO. 1980. Social and Cultural Impact of Tourist Movements. World Tourism Organization. Madrid: WTO 